\title{
New Insights on Astrocyte Ion Channels: Critical for Homeostasis and Neuron-Glia Signaling
}

\author{
Michelle L. Olsen, ${ }^{1}$ Baljit S. Khakh, ${ }^{2}$ SSerguei N. Skatchkov, ${ }^{3}$ Min Zhou, ${ }^{4}$ C. Justin Lee, ${ }^{5}$ and Nathalie Rouach ${ }^{6}$ \\ ${ }^{1}$ Department of Cell, Developmental and Integrative Biology, University of Alabama at Birmingham, Birmingham, Alabama 35294, ${ }^{2}$ Department of \\ Physiology and Neurobiology, David Geffen School of Medicine, University of California, Los Angeles, Los Angeles, California 90095, ${ }^{3}$ Department of \\ Biochemistry and Physiology, Universidad Central Del Caribe, Bayamón, Puerto Rico PR 00956, ${ }^{4}$ Department of Neuroscience, Ohio State University \\ Wexner Medical Center, Columbus, Ohio 43210, ${ }^{5}$ Center for Neuroscience and Functional Connectomics, Brain Science Institute, Korea Institute of Science \\ and Technology, Seoul, Republic of Korea, and ${ }^{\circ}$ Neuroglial Interactions in Cerebral Physiopathology, Center for Interdisciplinary Research in Biology, \\ Collège de France, INSERM U1050, CNRS UMR 7241, Labex Memolife, PSL Research University, Paris, France
}

Initial biophysical studies on glial cells nearly 50 years ago identified these cells as being electrically silent. These first studies also demonstrated a large $\mathrm{K}^{+}$conductance, which led to the notion that glia may regulate extracellular $\mathrm{K}^{+}$levels homeostatically. This view has now gained critical support from the study of multiple disease models discussed herein. Dysfunction of a major astrocyte $\mathrm{K}^{+} \mathrm{channel}$, Kir4.1, appears as an early pathological event underlying neuronal phenotypes in several neurodevelopmental and neurodegenerative diseases. An expanding list of other astrocyte ion channels, including the calcium-activated ion channel BEST-1, hemichannels, and two-pore domain $\mathrm{K}^{+}$channels, all contribute to astrocyte biology and CNS function and underpin new forms of crosstalk between neurons and glia. Once considered merely the glue that holds the brain together, it is now increasingly recognized that astrocytes contribute in several fundamental ways to neuronal function. Emerging new insights and future perspectives of this active research area are highlighted within.

\section{Significance Statement}

The critical role of astrocyte potassium channels in CNS homeostasis has been reemphasized by recent studies conducted in animal disease models. Emerging evidence also supports the signaling role mediated by astrocyte ion channels such as BEST1, hemichannels, and two-pore channels, which enable astrocytes to interact with neurons and regulate synaptic transmission and plasticity. This minisymposium highlights recent developments and future perspectives of these research areas.

\section{Introduction}

Next year (2016) marks the $50^{\text {th }}$ anniversary of the first physiology studies examining glial cells (Kuffler et al., 1966; Orkand et al., 1966). These and other early seminal studies demonstrated

Received July 6, 2015; revised Aug. 9, 2015; accepted Aug. 12, 2015.

This work was supported by National Institute of Neurological Disorders and Stroke (Grant R01 NS 075062 to M.L.O., Grant R01 NS060677 to B.S.K., Grant R01 NS065201 to S.N.S., Grant R01NS062784 to M.Z., and National Institute of Mental Health Grants R01MH099559 and DP1MH104069 to B.S.K.), INSERM (N.R.), Centre National de la Recherche Scientifique (N.R.), and Collège de France (N.R.), the Korea Institute of Science and Technology Institutional Program (Project No. 2E25472 to C.J.L.) and Brain Research Program through National Research Foundation of Korea funded by the Ministry of Science, ICT, and Future Planning (NRF-2012M3C7A1055412 to C.J.L.). The order of the authors reflects the order of their presentations at the Society for Neuroscience Minisymposium.

The authors declare no competing financial interests.

Correspondence should be addressed to either of the following: Dr. Min Zhou, Department of Neuroscience, Ohio State University, Wexner Medical Center, 333 W. 10th Ave., 4066c Graves Hall, Columbus OH 43210, E-mail: zhou.787@osu.edu; or Dr. Michelle L. Olsen, Department of Cell, Developmental and Integrative Biology, University of Alabama at Birmingham, 1918 University Blvd., MCLM 958, Birmingham, AL 35294, E-mail: molsen@uab.edu. DOI:10.1523/JNEUROSCI.2603-15.2015

Copyright $\odot 2015$ the authors $\quad 0270-6474 / 15 / 3513827-09 \$ 15.00 / 0$ that glial cells rest at quite hyperpolarized resting membrane potentials relative to neurons (by $>20 \mathrm{mV}$ ) and that glia display large and selective permeability to $\mathrm{K}^{+}$ions (Kuffler, 1967; Ransom and Goldring, 1973). Furthermore, due to the high selective $\mathrm{K}^{+}$permeability, the glial resting membrane potential was predicted by the Nernst equation for $\mathrm{K}^{+}$(Kuffler, 1967; Ransom and Goldring, 1973). These electrophysiological properties, the spatial arrangement in the CNS between astrocytes and neurons, and extensive astrocyte coupling via low-resistance intercellular pathways formed by gap junctions led to the formation of the $\mathrm{K}^{+}$ spatial buffering hypothesis.

The biophysical characteristics described above are still used today by neurophysiologists to identify astrocytes within in situ and in vivo preparations during electrophysiological recordings. Work from multiple groups of investigators indicates that the large $\mathrm{K}^{+}$leak conductance reflects the intrinsic property of membrane ion channels and appears to be a general functional feature of mature astrocytes (Dallérac et al., 2013; Du et al., 2015). Astro- 
cytes exhibit low input resistances, often $<20 \mathrm{M} \Omega$, as a result of the $\mathrm{K}^{+}$leak conductance, which represents a formidable barrier for the measurement of channel activity using traditional electrophysiological methods. This has proved particularly challenging for measuring ion flux at sites located distal to somata (Ma et al., 2014), particularly at perisynaptic and perivascular sites, where homeostatic support functions of $\mathrm{K}^{+}$channels are expected to contribute the most. The exact molecular signatures of the channels that orchestrate these membrane properties are unresolved, but appear to be due in part to the weakly rectifying $\mathrm{K}^{+}$channel Kir4.1 and two-pore domain $\mathrm{K}^{+}$channels. We discuss the latest findings of this critical channel in normal astrocyte and CNS function.

Work over the past two decades has led to multiple proposed pathways in astrocytes, such as $\mathrm{Ca}^{2+}$-dependent exocytotic release of ATP and glutamate, that maintain and regulate synaptic transmission/plasticity (Panatier et al., 2011; Agulhon et al., 2012a; Araque et al., 2014; Haydon and Nedergaard, 2015). Meanwhile, a growing list of channels that are not $\mathrm{K}^{+}$selective but are expressed in astrocytes has been revealed. These channels regulate neurotransmission through various novel mechanisms, which is the focus of this discussion. We term this group of channels "signaling channels," thus alluding to their primary involvement in astrocyte-neuron crosstalk. All of the signaling channels identified to date are poorly ion selective or nonselective cation/ anion channels. We briefly discuss the latest developments on the calcium-activated anion channel bestrophin1 (Best-1), connexin 43 hemichannels, and the two-pore $\mathrm{K}^{+}$channel TWIK-1 and TREK-1 (Lee et al., 2010; Woo et al., 2012; Wang et al., 2013; Chever et al., 2014). Although not an exhaustive list, these channels have received recent attention regarding astrocyte-neuron communication in the context of normal CNS function and in the pathological brain and will be discussed below.

\section{Kir4.1: an integral ion channel in astrocyte biology}

Kir4.1 is a weakly inwardly rectifying $\mathrm{K}^{+}$channel, which in the nervous system is expressed exclusively in glial cells, with highest expression in astrocytes. In astrocytes, putative functions of Kir4.1 include $\mathrm{K}^{+}$homeostasis, maintenance of the astrocyte resting membrane potential, high astrocyte $\mathrm{K}^{+}$conductance, astrocyte cell volume regulation, and facilitation of glutamate uptake (Olsen et al., 2006; Dibaj et al., 2007; Djukic et al., 2007; Kucheryavykh et al., 2007; Seifert et al., 2009). Increased Kir4.1 expression and function are associated with astrocyte maturation (Seifert et al., 2009), whereas reduced channel expression and/or activity is associated with the CNS pathologies such as epilepsy (Ferraro et al., 2004; Scholl et al., 2009), Alzheimer's disease (Wilcock et al., 2009), amyotrophic lateral sclerosis (Kaiser et al., 2006; Bataveljić et al., 2012), spinal cerebellar ataxia (Magaña et al., 2013), and pain (Vit et al., 2008). Pharmacological inhibition, knock-down, or complete knock-out of this channel results in astrocytes with increased membrane resistance, depolarized resting membrane potentials, and in extracellular potassium dynamics (Olsen et al., 2006; Kucheryavykh et al., 2007; Seifert et al., 2009; Chever et al., 2010; Sibille et al., 2015). Furthermore, studies using glia-specific conditional Kir4.1 knock-out mice or siRNA-mediated silencing of the gene indicate that loss of this ion channel results in aberrations in glutamate homeostasis (Djukic et al., 2007; Kucheryavykh et al., 2007), possibly by affecting astrocyte resting membrane potential or some other unknown direct/indirect interaction between Kir4.1 and glutamate transporters. In addition to cell-intrinsic glial cell dysfunction, loss of Kir4.1 affects neuronal function, as indicated by alterations in hippocampal short-term plasticity (Sibille et al., 2014). Furthermore, ataxia, seizures, and early postnatal death (before postnatal day 25) in mice lacking Kir4.1 underscore the importance of the channel for normal CNS function. Mutations in the Kir4.1 gene (KCNJ10) are causative for the autosomal recessive disorder, SeSAME/EAST Syndrome (Seizures, Sensorineural deafness, Ataxia, Mental retardation and Electrolyte imbalance/Epilepsy, Ataxia, Sensorineural deafness and Tubulopathy) in human patients (Bockenhauer et al., 2009; Scholl et al., 2009). Neurological features of this syndrome include early onset seizures, ataxia, epilepsy, sensorineural hearing loss, cognitive impairments, and developmental delay. Furthermore, there exist subsets of patients diagnosed with autism and seizures who harbor mutations in the Kir4.1 channel (Sicca et al., 2011). These data suggest that glial Kir4.1 serves an important role in early CNS neuronal development and functioning.

\section{Kir4.1 dysfunction in the neurodevelopmental disorder of Rett syndrome}

Rett syndrome (RTT) is a devastating neurodevelopmental disorder, which is caused by spontaneous mutations in the X-linked transcriptional regulator methyl $\mathrm{CpG}$ binding protein 2 (MeCP2) in $>95 \%$ cases (Neul et al., 2010). MeCP2 binds to methylated or unmethylated DNA to modulate gene transcription (Chahrour et al., 2008). RTT is a leading cause of cognitive, motor, and communication impairment in females, affecting 1:10,000-15,000 female births worldwide each year. Loss of speech, seizures, ataxia, dystonia, stereotypies, and irregular breathing with hyperventilation/apnea while awake, difficulty swallowing, and pervasive growth failure, along with severe gastrointestinal disorders are just some of the problems that plague RTT patients (Neul et al., 2010). Although typically thought of as a neuronal disease, a recent study showed that reexpression of MeCP2 exclusively in astrocytes ameliorates or prevents overt symptoms in animal models of RTT (Lioy et al., 2011), demonstrating that astrocytes contribute significantly to the etiology of the disease. However, the mechanisms by which astrocytes contribute to RTT have not yet been identified.

RTT shares many common features with the SeSAME/EAST syndrome, which is caused by loss-of-function mutations in Kir4.1. The constellation of SeSAME/EAST syndrome neurological symptoms includes severe developmental delay, early onset seizures ( 3-6 months of age), ataxia, lower motor extremity weakness, and sensorineural deafness (Scholl et al., 2009; Tang et al., 2010). The onset and early progression of neurological symptoms may be explained by reductions in functional Kir4.1, which typically demonstrates marked upregulation during late fetal and early postgestational development in human CNS (Kang et al., 2011; Fig. 1). Similar developmental increases in Kir4.1 mRNA and protein are observed in rodents (Poopalasundaram et al., 2000; Dibaj et al., 2007; Nwaobi et al., 2014). It was demonstrated that the transcriptional upregulation of KCNJ10 is coincident with reductions in DNA methylation patterns of the gene. Manipulation of the methylation status of KCNJ10 was sufficient to modify gene transcription (Nwaobi et al., 2014). As with many highly transcribed genes, the promoter region of KCNJ10 is lowly methylated. Given that MeCP2 binds to lowly methylated gene promoters to activate gene transcription (Yasui et al., 2007), it was postulated that $\mathrm{MeCP} 2$ may directly regulate $\mathrm{KCNJ10}$ gene transcription. Supporting this, we observed a significant difference in Kir4.1 protein expression and function in a commonly used murine model of RTT (M. L. Olsen, V. A. Cuddapah, N. L. Pacheco, unpublished results). Interestingly, reduced Kir4.1 protein loss was observed early in postnatal development and before 


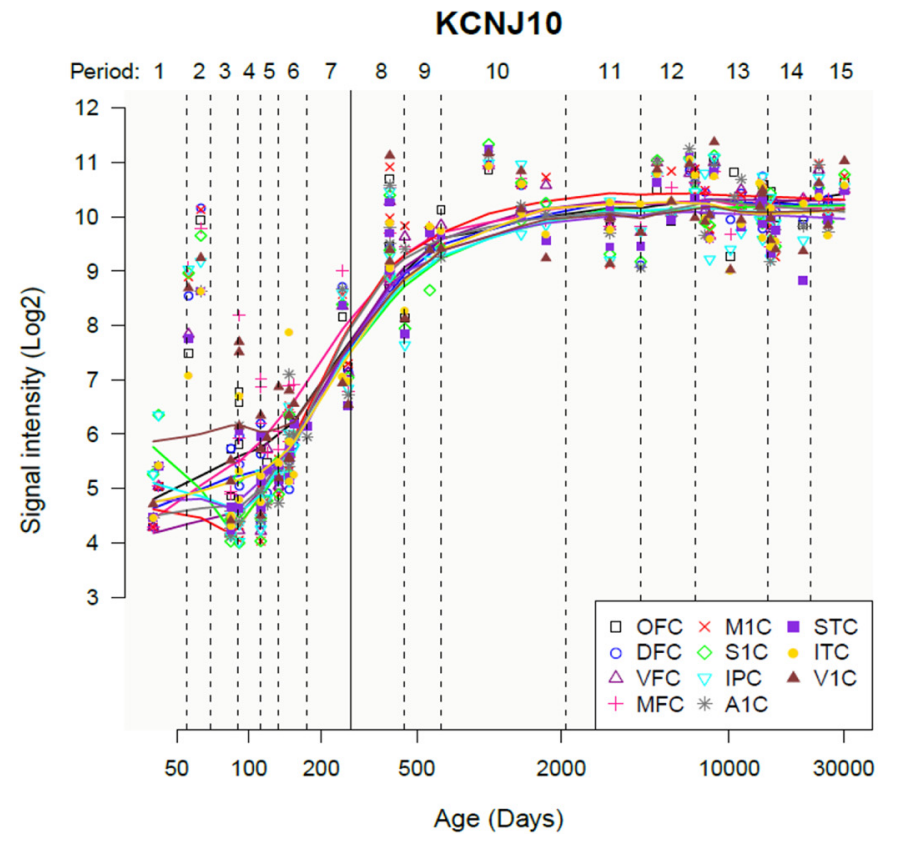

Period (days post-conception)

1 Embryonic 4PCW\#Age,8PCW

2 Early fetal $8 \mathrm{PCW} \#$ Age, $10 \mathrm{PCW}$

3 Early fetal 10PCW\#Age, 13PCW

4 Early mid-fetal 13PCW\#Age, 16PCW

5 Early mid-fetal 16PCW\#Age, 19PCW

6 Late mid-fetal 19PCW\#Age, 24PCW

7 Late fetal 24PCW\#Age,38PCW

8 Neonatal and early infancy $0 \mathrm{M}$ (birth)\#Age, $6 \mathrm{M}$

9 Late infancy $6 \mathrm{M} \# \mathrm{Age}, 12 \mathrm{M}$

10 Early childhood 1 Y\#Age,6Y

11 Middle and late childhood 6 Y\#Age, 12 Y

12 Adolescence $12 \mathrm{Y}$ \#Age, $20 \mathrm{Y}$

13 Young adulthood 20 Y\#Age, $40 \mathrm{Y}$

14 Middle adulthood $40 \mathrm{Y} \#$ Age, $60 \mathrm{Y}$

15 Late adulthood $60 \mathrm{Y \# Age}$

Cortical region

OFC-orbital prefrontal cortex

DFC-dorsolateral prefrontal cortex

VFC- ventrolateral prefrontal cortex

MFC-medial prefrontal cortex

M1C- primary motor (M1) cortex

S1C- primary somatosensory (S1) cortex

IPC- posterior inferior parietal cortex

A1C- primary auditory (Al) cortex

STC- superior temporal cortex

ITC- inferior temporal cortex

V1C-primary visual (V1) cortex

Figure 1. KCNJ10 expression is upregulated during late fetal and early postnatal development. In human cortex, KCNJ10 expression begins to show significant increase during late middle to late fetal development and continues to increase through early childhood. Expression stabilizes between early ( $<6$ years of age) and middle to late childhood ( 12 years of age). Similar temporal patterns of expression were observed in amygdala, hippocampus, striatum, and medial dorsal nucleus of the thalamus (data not shown). Figure reprinted with permission (Kang et al., 2011).

the observation of RTT-like symptoms in mice. A ChIP assay revealed a direct interaction between the $\mathrm{MeCP} 2$ protein and the Kir4.1 gene promoter in WT mice that was absent in RTT mice. Together, these data suggest that MeCP2 positively modulates Kir4.1 gene transcription. Current studies are under way to determine whether alterations in astrocyte Kir4.1 expression and function play a direct role in RTT pathogenesis.

\section{Dysfunction of astrocyte Kir4.1 occurs early on in Huntington's disease model mice}

Huntington's disease (HD) is characterized by motor, cognitive, and psychiatric disturbances associated with neuronal dysfunction and atrophy of the striatum and other brain areas. HD is caused by an expanded chain of polyglutamines localized to the $\mathrm{N}$-terminal region of the huntingtin protein that causes intracellular accumulation and aggregation of mutant huntingtin (Mangiarini et al., 1996). The molecular, cellular, and basal ganglia circuit mechanisms that produce disease phenotypes remain incompletely understood, although effort has focused on mutant huntingtin (mHTT) expression within neurons. Several recent studies suggest that astrocytes are also involved in HD (Shin et al., 2005; Bradford et al., 2009; Faideau et al., 2010), which extends data showing that brains from HD patients and from mouse models of HD have mHTT accumulation in striatal astrocytes (Shin et al., 2005; Faideau et al., 2010). Much remains unknown about how astrocytes contribute to HD pathogenesis.

Recently, it was discovered that Kir4.1 potassium ion channel expression was decreased in astrocytes that express mHTT (Tong et al., 2014), with little or no evidence for reactive astrogliosis at symptom onset in the transgenic R6/2 and knock-in Q175 mouse models of HD. The loss of a $\mathrm{K}^{+}$conductance depolarized astrocytes and medium spiny neurons in vitro and likely contributed to elevated levels of $\mathrm{K}^{+}$that were measured in vivo within the striatum of HD model mice (Tong et al., 2014). Moreover, rescuing the loss of astrocyte Kir4.1 reduced several deficits associated with HD mouse models (Tong et al., 2014). Unexpectedly, restoring the loss of astrocyte Kir4.1 rescued astrocyte glutamate transporter Glt1 expression. This serendipitous observation was of relevance to the human disease because Glt1 levels are known to be reduced in HD and because Glt1 is heavily implicated in disease mechanisms (Liévens et al., 2001; Miller et al., 2008; Estrada-Sánchez and Rebec, 2012). Further detailed studies to explore signaling by astrocyte Kir4.1 channels, Glt-1 expression, and their functional relevance are needed. Nevertheless, the available data suggest that basal ganglia circuit level defects in HD and other brain disorders may be partly remedied by correcting key astrocyte dysfunctions that have ensuing consequences for neurons, microcircuits, and their outputs.

\section{Regulation of Kir4.1 by intracellular spermine}

Unlike typical voltage-gated ion channels, which gate in response to membrane depolarization, the pore of Kir4.1 is blocked at depolarized potentials by $\mathrm{Mg}^{2+}$ ions and polyamines. At or near the reversal potential for potassium $\left(E_{\mathrm{K}}\right)$, the block is removed and $\mathrm{K}^{+}$ions permeate the pore (Oliver et al., 1998; Tada et al., 1998). The direction of flux is determined by the electrochemical gradient for $\mathrm{K}^{+}$. Kir4.1, as originally described, was characterized as having intermediate rectification properties (Tada et al., 1998). An attractive idea put forth in this study was that features of channel rectification would allow for both $\mathrm{K}^{+}$influx and efflux through the same channel, thus making this channel ideally suited for the regulation of $\mathrm{K}^{+}$concentrations. The rectification properties of Kir4.1, like all other inward-rectifying $\mathrm{K}^{+}$channels, are governed by intracellular polyamines (Guo and Lu, 2002). (Oliver et al., 1998). Polyamines such as spermine are ubiquitous biogenic molecules essential for all mammalian cells (Pegg, 2014). Spermine is implicated in many cellular processes ranging from transcription to nucleic acid stability. Intriguing, spermine is selectively accumulated in astrocytes (Laube and Veh, 1997) and physiological concentration of polyamine is crucial for the opening status of connexin43 (Skatchkov et al., 2000; 
Skatchkov et al., 2014). Therefore, the polyamine spermine may be critical for the integrative function of astrocytes at the syncytial level. For example, holding the cytoplasmic concentration of spermine at $1 \mathrm{~mm}$, a physiologically relevant concentration (Kucheryavykh et al., 2008; Skatchkov et al., 2014), while applying 10-100 $\mu \mathrm{M}$ glutamate externally to activate $\mathrm{Na}^{+}$-dependent glutamate uptake resulted in an increase of intracellular $\mathrm{Na}^{+}$concentration of $\sim 10$ $\mathrm{mM}$ and a switch of $\mathrm{K}^{+}$currents from weakly to strongly rectifying in both cortical astrocytes and retinal Müller glia (Kucheryavykh et al., 2008). These data suggest that $\mathrm{Na}^{+}$, such as through glutamate transporters, can optimize glial Kir4.1 function. Interestingly, polyamine biosynthesis and concentrations vary during cell cycle progression (Oredsson, 2003) and differing metabolic demands on the cell (Kauppinen and Alhonen, 1995). It is conceivable that the gating properties of Kir4.1, and therefore flux through the channel in astrocytes, are dependent on parameters that govern astrocyte polyamine and $\mathrm{Na}^{+}$concentrations. Given that Kir4.1 is expressed in astrocytes throughout the CNS, intracellular polyamine and $\mathrm{Na}^{+}$concentrations may permit astrocytes to customize ion flux according to regional demands.

\section{Mutations in the Kir4.1 gene, KCNJ10}

As mentioned above, mutations in the Kir4.1 gene, KCNJ10, are causative for SeSAME/EAST syndrome in human patients. The predicted structure of a single Kir4.1 subunit, the identified mutations, and the respective amino acid changes are shown in Figure 2. Deficits in channel function were revealed using heterologous expression systems for each identified mutation. Homomeric expression of five mutations identified in the human population (R199Stop, C140R, T164I, G77R, and R297C) revealed a near complete loss of function at physiological pH (Sala-Rabanal et al., 2010; Tang et al., 2010). In contrast, R65P and A167V mutants conducted $\mathrm{K}^{+}$ions, but significantly less so than WT KCNJ10 (Sala-Rabanal et al., 2010). Coexpression with the Kir5.1 subunit, which is thought to form heteromeric channels with Kir4.1 in some instances, did not rescue channel dysfunction of Kir4.1 mutants. In contrast, channel function was rescued with coexpression with wild-type Kir4.1 channels (Sala-Rabanal et al., 2010), suggesting that, in humans, Kir4.1 is composed of homomeric subunits.

\section{Channels with signaling functions in astrocytes}

Functions for signaling channels range from regulation of brain development to synaptogenesis, synaptic transmission and plasticity, and functional neuron-astrocyte-vascular coupling (Lalo et al., 2011; Illes et al., 2012; Scemes and Spray, 2012; Filosa et al., 2013; Verkhratsky et al., 2014).
TREK-1 as a glutamate release channel and TWIK-1 as a sensor of glutamatergic transmission

In the quest for a full understanding of $\mathrm{K}^{+}$channel expression profiles, TWIK-1 and TREK-1, two of the two-pore domain $\mathrm{K}^{+}$ channel $\left(\mathrm{K}_{2 \mathrm{p}}\right)$ isoforms, came into the focus as promising candidates (Fig. 3; Cahoy et al., 2008). Interestingly, membrane TREK-1 provides a fast glutamate release pathway upon activation of $\mathrm{G}_{\alpha \mathrm{i}}$ coupled GPCR, and glutamate release is triggered by interaction of dissociated $\mathrm{G} \beta \gamma$ with the $\mathrm{N}$ terminus of TREK-1 channels (Woo et al., 2012). However, whether TWIK-1 contributes as a classic $\mathrm{K}^{+}$channel to the astrocyte's passive conductance is not yet resolved (Zhou et al., 2009; Wang et al., 2013; Hwang et al., 2014). Interestingly, this channel has attracted attention because of its peculiar ion conduction and trafficking features. Similar to kidney tubular and pancreatic $\beta$ cells, a large amount of TWIK-1 is retained in intracellular compartments. When trafficked to the plasma membrane, TWIK-1 is a nonselective monovalent cation channel (Millar et al., 2006; Chatelain et al., 2012; Wang et al., 2013). Recent work has demonstrated that TWIK-1 inward $\mathrm{NH}_{4}{ }^{+}$currents were 40 -fold larger than those carried by $\mathrm{K}^{+}$(Ma et al., 2012), implying that TWIK-1 is an efficient $\mathrm{NH}_{4}{ }^{+}$ uptake channel in astrocytes. In addition, membrane TWIK-1 expression can be regulated by $G_{\mathrm{i}} / G_{\mathrm{o}}$-coupled receptors such as the 5-HT and $\alpha 2$-adrenoceptor receptors (Feliciangeli et al., 2010). The $G_{\mathrm{i}}$-coupled metabotropic glutamate receptor 3 (mGluR3) is the predominant mGluR isoform in cortical and hippocampal astrocytes in adult mice (Sun et al., 2013; Haustein et al., 2014). This places mGluR3 as the predominant metabotropic glutamate receptor expressed in hippocampal astrocytes sensing dynamic changes in glutamatergic synaptic transmission, which occur under physiological and pathological conditions in the CNS. Both proteins, mGluR3 and TWIK-1, are highly expressed in astrocytes, prompting the hypothesis that activation of 
A

A

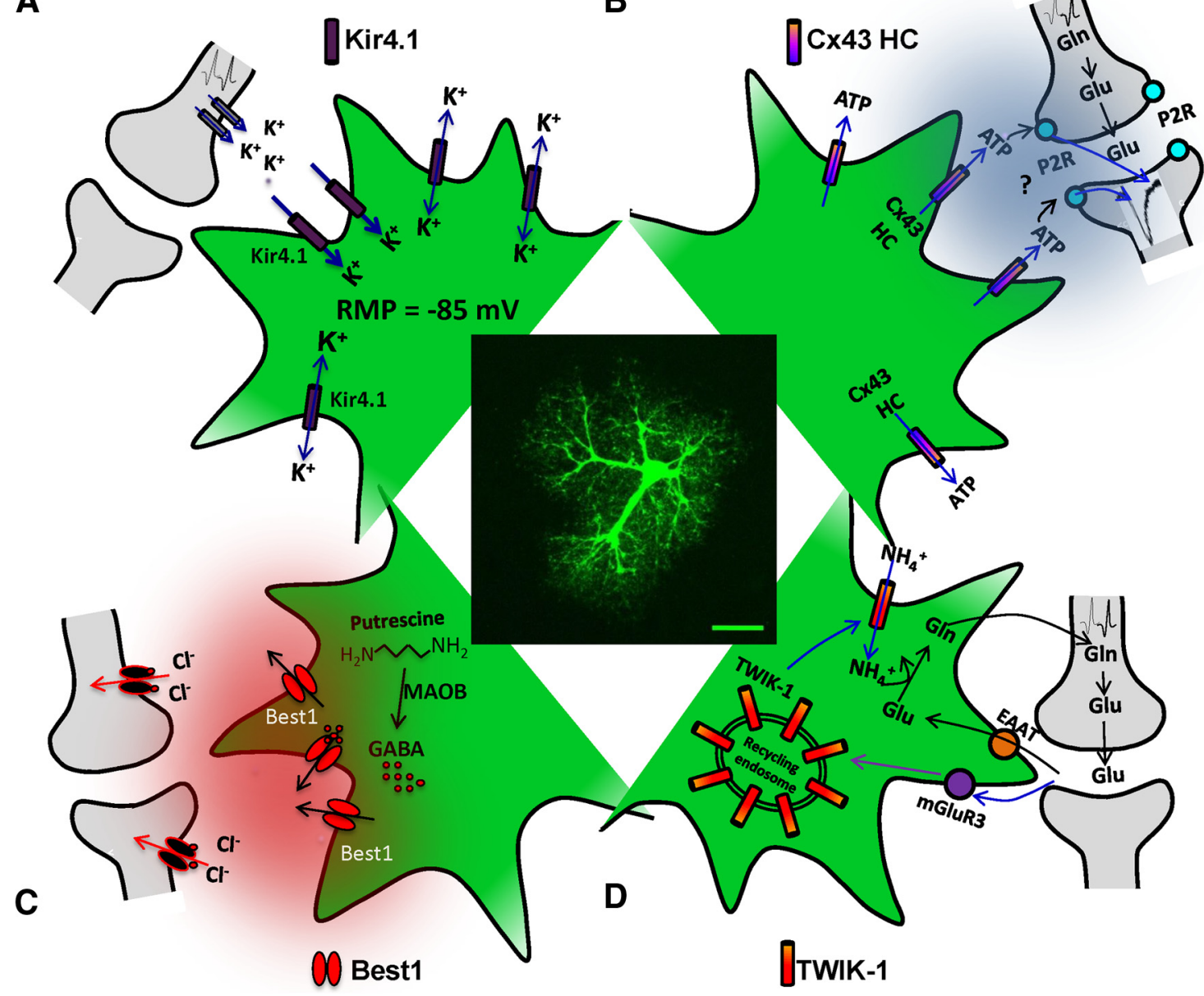

Figure 3. Role of astrocyte $\mathrm{K}^{+}$and signaling channels. Shown is a confocal image of a hippocampal astrocyte in situ revealed by intracellular loading of Alexa Fluor-488 (courtesy of Jonathan Zapata). Scale bar, $20 \mu \mathrm{m}$. $\boldsymbol{A}$, Kir 4.1 functions as a major $\mathrm{K}^{+}$channel establishing hyperpolarized astrocyte membrane potential and spatially redistributing the $\mathrm{K}^{+}$concentration. $\boldsymbol{B}, \mathrm{Cx} \mathrm{A3}$ hemichannels modulate basal glutamatergic synaptic activity through ATP signaling. In basal conditions, (x43 hemichannels boost hippocampal excitatory postsynaptic activity through ATP signaling. A possible scenario is that $\mathrm{CX} 43$ hemichannels release ATP, which activates P2 receptors on CA1 pyramidal cells that increase glutamatergic postsynaptic activity. C, Astrocytic GABA is produced via putrescine degradation pathway with a key biosynthetic enzyme, $\mathrm{MAOB}$. GABA release from Best1 contributes significantly to the tonic GABA release under physiological and various pathologic conditions. D, Activation of mGluR3 translocates TWIK-1 from recycling endosome to membrane that enhances $\mathrm{NH}_{4}{ }^{+}$uptake, which may facilitate glutamine-glutamate cycle for replenishment of neurotransmitters in neurons.

mGluR3 recruits cytoplasmic TWIK-1 channels to membrane in hippocampal astrocytes (W. Wang, C. M. Kiyoshi, Y. Du, B. Ma, M. Zhou, unpublished observation). Activation of mGluR3 increased membrane TWIK-1 expression through a Rab-mediated endosomal recycling pathway. Functionally, increased membrane TWIK-1 expression was associated with elevated $\mathrm{NH}_{4}{ }^{+}$ uptake. Therefore, neuronal glutamate release may regulate TWIK-1 membrane expression and $\mathrm{NH}_{4}{ }^{+}$uptake dynamically in astrocytes, which in turn provide glutamine for neurotransmitter renewal through the glutamate-glutamine cycle.

\section{Bestl's role in tonic GABA release and neurological diseases}

Bestrophin (Best) is the gene responsible for a dominantly inherited, juvenile-onset form of macular degeneration called Best vitelliform macular dystrophy. It has been shown to encode a functional $\mathrm{Ca}^{2+}$-activated anion channel that is activated directly by submicromolar intracellular $\mathrm{Ca}^{2+}$ in nonneuronal tissues and peripheral neurons (Hartzell et al., 2008). Several studies have suggested the function of Best in various physiological processes such as normal vision and cell volume regulation (Hartzell et al., 2008; Milenkovic et al., 2015). In the brain, Best1 was found to be largely expressed in astrocytes (Park et al., 2009; Oh et al., 2012), especially at the microdomains near synaptic junctions (Woo et al., 2012; Park et al., 2013). As an ion channel, Best1 shows a relatively high permeability to large anions, including glutamate and isethionate, along with chloride ions (Park et al., 2009; Park et al., 2013). It has been demonstrated that astrocytes release glutamate via Best1 (Woo et al., 2012), which then targets and activates synaptically localized, GluN2A-containing NMDA receptors in hippocampal CA1 pyramidal neurons (Han et al., 2013) to modulate hippocampal synaptic plasticity (Park et al., 2015).

In addition to glutamate, Best1 has a significant permeability to gamma aminobutyric acid (GABA) and mediates its tonic release from astrocytes in cerebellum to strongly inhibit neuronal excitability (Lee et al., 2010). GABA release from astrocytes may contribute significantly to tonic release of GABA observed in many brain regions under physiological conditions, as well as under various pathological conditions. Tonic inhibition is highly correlated with the presence of cytosolic GABA in cerebellum and hippocampus and other brain regions (Yoon et al., 2011); tonic inhibition was high and immunostaining for GABA in astrocytes was high in cerebellum, whereas tonic inhibition was low and 
immunostaining for GABA was low in astrocytes in CA1 hippocampus. Astrocytic GABA is produced via putrescine degradation pathway with monoamine oxidase $\mathrm{B}$ (MAOB) as a key biosynthetic enzyme (Yoon et al., 2014). Therefore, under physiological conditions, astrocytic GABA is synthesized by MAOB and released by Best1 when there are sufficient levels of cytosolic GABA.

Astrocytic GABA is elevated in pathological conditions such as Alzheimer's disease. Reactive hippocampal astrocytes near amyloid plaques contain high levels of GABA (Jo et al., 2014; Wu et al., 2014), show elevated putrescine and use MAOB to produce GABA (Jo et al., 2014). Because reactive astrocytes in Alzheimer's disease model mice showed elevated $\mathrm{Ca}^{2+}$ levels (Kuchibhotla et al., 2009), the synthesized GABA was readily released through Best1 (Jo et al., 2014). Interestingly, elevated GABA is associated with altered distribution patterns of Best1, from a microdomainspecific to soma- and process-specific expression patterns (Jo et al., 2014). These results demonstrate the dynamic nature of Best1: the functional switch and differential trafficking from physiological conditions to pathological conditions and from glutamate releasing at synaptic junction to tonic GABA release at soma and processes. In conclusion, Bestl's role in GABA release may be important in the context of gliosis observed in neurodegenerative diseases.

\section{Astrocyte connexin hemichannels shape basal synaptic transmission}

Astrocytes express high level of connexins (Cxs), the protein subunits forming gap junction channels that mediate the extensive astrocyte network communication (Pannasch and Rouach, 2013). Each gap junction channel is formed by the alignment of two hemichannels (HCs), and the connexons are composed of six transmembrane proteins. In astrocytes, the primary connexons are Cxs 43 and 30. Astrocyte Cxs contribute to synaptic strength or memory in physiological conditions, notably by regulating neurometabolic coupling (Rouach et al., 2008), extracellular homeostasis (Wallraff et al., 2006; Pannasch et al., 2011), astrocyte synapse coverage (Pannasch et al., 2014), or gliotransmitter release (Stehberg et al., 2012; Torres et al., 2012; Chever et al., 2014). In contrast to gap junctions, astrocyte hemichannels mediate direct exchange with the extracellular space and, remarkably, Cxs also demonstrate channel-independent functions involving protein interactions and/or cell adhesion (Theis et al., 2005; Elias and Kriegstein, 2008; Pannasch and Rouach, 2013; Pannasch et al., 2014). Cx HCs represent an important pathway of release or uptake of ions and signaling molecules in astrocytes (Giaume et al., 2013; Cheung et al., 2014). Initially, Cx HCs were thought to be activated primarily during pathological situations because their opening was viewed as deleterious by inducing loss of cytoplasmic integrity and neurotoxic damage (Giaume et al., 2013; Cheung et al., 2014). However, several recent studies suggest emerging physiological functions that include the regulation of synaptic activity and memory through gliotransmitter release (Stehberg et al., 2012; Torres et al., 2012; Cheung et al., 2014; Chever et al., 2014).

Astrocyte Cx43 HCs are open under resting conditions in acute hippocampal slices and tune basal glutamatergic synaptic transmission via ATP signaling (Chever et al., 2014). To investigate whether such opening of $\mathrm{Cx} 43 \mathrm{HCs}$ regulates basal synaptic transmission, EPSCs from hippocampal CA1 pyramidal cells were investigated. A rapid decrease in EPSCs was seen upon acute inhibition of $\mathrm{Cx} 43$ HCs with the mimetic blocking peptide Gap26, indicating that astrocyte Cx43 HCs endogenously strengthen basal glutamatergic synaptic transmission. Remarkably, basal extracellular ATP levels, measured locally and in real time in hippocampal slices using a luciferin-luciferase luminescence assay, were also concurrently decreased by the Gap26blocking peptide, suggesting that ATP is released tonically through $\mathrm{Cx} 43 \mathrm{HCs}$ in resting conditions. To investigate whether ATP release by $\mathrm{Cx} 43 \mathrm{HCs}$ modulates excitatory synaptic transmission in hippocampal slices through direct activation of ATP purinergic receptors, the ATP $\mathrm{P} 2 \mathrm{X}$ and $\mathrm{P} 2 \mathrm{Y}$ receptors were acutely blocked. This treatment mimicked the decreased excitatory synaptic transmission induced by Gap 26 inhibition of $\mathrm{Cx} 43$ HCs and also occluded the effect of Gap26 on synaptic transmission. Basal extracellular ATP levels resulting from Cx43 HCmediated ATP release thus exert a tonic facilitation of hippocampal excitatory transmission by direct activation of ATP purinergic receptors. Together, these data reveal Cx43 HCs as a novel physiological pathway of ATP release strengthening the moment-to-moment excitatory synaptic transmission in the hippocampus.

\section{Conclusions}

Astrocytes are the most numerous cells in the CNS. They tile the entire brain and serve vital trophic, active, and homeostatic roles (Barres, 2008). Growing evidence indicates that astrocytes contribute to neurological and psychiatric disorders (Maragakis and Rothstein, 2006; Barres, 2008; Ilieva et al., 2009; Nedergaard et al., 2010; Agulhon et al., 2012b; Clarke and Barres, 2013). However, key questions about astrocyte engagement in neural circuits, such as whether active or homeostatic roles dominate, remain unclear. Overall, deciphering the precise settings under which astrocytes contribute to neuronal circuit function in health and disease has proven challenging (Khakh and McCarthy, 2015) and a clearer understanding of the critical processes mediated by this cell type will illuminate how the healthy CNS functions and provide insight into pathological disease mechanisms.

\section{References}

Agulhon C, Sun MY, Murphy T, Myers T, Lauderdale K, Fiacco TA (2012a) Calcium signaling and gliotransmission in normal vs. reactive astrocytes. Front Pharmacol 3:139. Medline

Agulhon C, Sun MY, Murphy T, Myers T, Lauderdale K, Fiacco TA (2012b) Calcium Signaling and Gliotransmission in Normal vs. Reactive Astrocytes. Front Pharmacol 3:139.

Araque A, Carmignoto G, Haydon PG, Oliet SH, Robitaille R, Volterra A (2014) Gliotransmitters travel in time and space. Neuron 81:728-739. CrossRef Medline

Barres BA (2008) The mystery and magic of glia: a perspective on their roles in health and disease. Neuron 60:430-440. CrossRef Medline

Bataveljić D, Nikolić L, Milosević M, Todorović N, Andjus PR (2012) Changes in the astrocytic aquaporin- 4 and inwardly rectifying potassium channel expression in the brain of the amyotrophic lateral sclerosis SOD1(G93A) rat model. Glia 60:1991-2003. CrossRef Medline

Bockenhauer D, Feather S, Stanescu HC, Bandulik S, Zdebik AA, Reichold M, Tobin J, Lieberer E, Sterner C, Landoure G, Arora R, Sirimanna T, Thompson D, Cross JH, van't Hoff W, Al Masri O, Tullus K, Yeung S, Anikster Y, Klootwijk E, et al. (2009) Epilepsy, ataxia, sensorineural deafness, tubulopathy, and KCNJ10 mutations. N Engl J Med 360:19601970. CrossRef Medline

Bradford J, Shin JY, Roberts M, Wang CE, Li XJ, Li S (2009) Expression of mutant huntingtin in mouse brain astrocytes causes age-dependent neurological symptoms. Proc Natl Acad Sci U S A 106:22480-22485. CrossRef Medline

Cahoy JD, Emery B, Kaushal A, Foo LC, Zamanian JL, Christopherson KS, Xing Y, Lubischer JL, Krieg PA, Krupenko SA, Thompson WJ, Barres BA (2008) A transcriptome database for astrocytes, neurons, and oligodendrocytes: a new resource for understanding brain development and function. J Neurosci 28:264-278. CrossRef Medline

Chahrour M, Jung SY, Shaw C, Zhou X, Wong ST, Qin J, Zoghbi HY (2008) 
MeCP2, a key contributor to neurological disease, activates and represses transcription. Science 320:1224-1229. CrossRef Medline

Chatelain FC, Bichet D, Douguet D, Feliciangeli S, Bendahhou S, Reichold M, Warth R, Barhanin J, Lesage F (2012) TWIK1, a unique background channel with variable ion selectivity. Proc Natl Acad Sci U S A 109:54995504. CrossRef Medline

Cheung G, Chever O, Rouach N (2014) Connexons and pannexons: newcomers in neurophysiology. Front Cell Neurosci 8:348. Medline

Chever O, Djukic B, McCarthy KD, Amzica F (2010) Implication of Kir4.1 channel in excess potassium clearance: an in vivo study on anesthetized glial-conditional Kir4.1 knock-out mice. J Neurosci 30:15769-15777. CrossRef Medline

Chever O, Lee CY, Rouach N (2014) Astroglial connexin43 hemichannels tune basal excitatory synaptic transmission. J Neurosci 34:11228-11232. CrossRef Medline

Clarke LE, Barres BA (2013) Emerging roles of astrocytes in neural circuit development. Nat Rev Neurosci 14:311-321. CrossRef Medline

Dallérac G, Chever O, Rouach N (2013) How do astrocytes shape synaptic transmission? Insights from electrophysiology. Front Cell Neurosci 7:159. Medline

Dibaj P, Kaiser M, Hirrlinger J, Kirchhoff F, Neusch C (2007) Kir4.1 channels regulate swelling of astroglial processes in experimental spinal cord edema. J Neurochem 103:2620-2628. Medline

Djukic B, Casper KB, Philpot BD, Chin LS, McCarthy KD (2007) Conditional knock-out of Kir4.1 leads to glial membrane depolarization, inhibition of potassium and glutamate uptake, and enhanced short-term synaptic potentiation. J Neurosci 27:11354-11365. CrossRef Medline

Du Y, Ma B, Kiyoshi CM, Alford CC, Wang W, Zhou M (2015) Freshly dissociated mature hippocampal astrocytes exhibit passive membrane conductance and low membrane resistance similarly to syncytial coupled astrocytes. J Neurophysiol 113:3744-3750. CrossRef Medline

Elias LA, Kriegstein AR (2008) Gap junctions: multifaceted regulators of embryonic cortical development. Trends Neurosci 31:243-250. CrossRef Medline

Estrada-Sánchez AM, Rebec GV (2012) Corticostriatal dysfunction and glutamate transporter 1 (GLT1) in Huntington's disease: interactions between neurons and astrocytes. Basal Ganglia 2:57-66. CrossRef Medline

Faideau M, Kim J, Cormier K, Gilmore R, Welch M, Auregan G, Dufour N, Guillermier M, Brouillet E, Hantraye P, Déglon N, Ferrante RJ, Bonvento G (2010) In vivo expression of polyglutamine-expanded huntingtin by mouse striatal astrocytes impairs glutamate transport: a correlation with Huntington's disease subjects. Hum Mol Genet 19:3053-3067. CrossRef Medline

Feliciangeli S, Tardy MP, Sandoz G, Chatelain FC, Warth R, Barhanin J, Bendahhou S, Lesage F (2010) Potassium channel silencing by constitutive endocytosis and intracellular sequestration. J Biol Chem 285:47984805. CrossRef Medline

Ferraro TN, Golden GT, Smith GG, Martin JF, Lohoff FW, Gieringer TA, Zamboni D, Schwebel CL, Press DM, Kratzer SO, Zhao H, Berrettini WH, Buono RJ (2004) Fine mapping of a seizure susceptibility locus on mouse Chromosome 1: nomination of Kcnj10 as a causative gene. Mamm Genome 15:239-251. CrossRef Medline

Filosa JA, Yao X, Rath G (2013) TRPV4 and the regulation of vascular tone. J Cardiovasc Pharmacol 61:113-119. CrossRef Medline

Giaume C, Leybaert L, Naus CC, Sáez JC (2013) Connexin and pannexin hemichannels in brain glial cells: properties, pharmacology, and roles. Front Pharmacol 4:88. Medline

Guo D, Lu Z (2002) IRK1 inward rectifier K(+) channels exhibit no intrinsic rectification. J Gen Physiol 120:539-551. CrossRef Medline

Han KS, Woo J, Park H, Yoon BJ, Choi S, Lee CJ (2013) Channel-mediated astrocytic glutamate release via Bestrophin-1 targets synaptic NMDARs. Mol Brain 6:4. CrossRef Medline

Hartzell HC, Qu Z, Yu K, Xiao Q, Chien LT (2008) Molecular physiology of bestrophins: multifunctional membrane proteins linked to best disease and other retinopathies. Physiol Rev 88:639-672. CrossRef Medline

Haustein MD, Kracun S, Lu XH, Shih T, Jackson-Weaver O, Tong X, Xu J, Yang XW, O'Dell TJ, Marvin JS, Ellisman MH, Bushong EA, Looger LL, Khakh BS (2014) Conditions and constraints for astrocyte calcium signaling in the hippocampal mossy fiber pathway. Neuron 82:413-429. CrossRef Medline

Haydon PG, Nedergaard M (2015) How do astrocytes participate in neural plasticity? Cold Spring Harb Perspect Biol 7:a020438. CrossRef Medline
Hwang EM, Kim E, Yarishkin O, Woo DH, Han KS, Park N, Bae Y, Woo J, Kim D, Park M, Lee CJ, Park JY (2014) A disulphide-linked heterodimer of TWIK-1 and TREK-1 mediates passive conductance in astrocytes. Nat Commun 5:3227. Medline

Ilieva H, Polymenidou M, Cleveland DW (2009) Non-cell autonomous toxicity in neurodegenerative disorders: ALS and beyond. J Cell Biol 187: 761-772. CrossRef Medline

Illes P, Verkhratsky A, Burnstock G, Franke H (2012) P2X receptors and their roles in astroglia in the central and peripheral nervous system. Neuroscientist 18:422-438. CrossRef Medline

Jo S, Yarishkin O, Hwang YJ, Chun YE, Park M, Woo DH, Bae JY, Kim T, Lee J, Chun H, Park HJ, Lee da Y, Hong J, Kim HY, Oh SJ, Park SJ, Lee H, Yoon BE, Kim Y, Jeong Y, et al. (2014) GABA from reactive astrocytes impairs memory in mouse models of Alzheimer's disease. Nat Med 20: 886-896. CrossRef Medline

Kaiser M, Maletzki I, Hülsmann S, Holtmann B, Schulz-Schaeffer W, Kirchhoff F, Bähr M, Neusch C (2006) Progressive loss of a glial potassium channel (KCNJ10) in the spinal cord of the SOD1 (G93A) transgenic mouse model of amyotrophic lateral sclerosis. J Neurochem 99:900-912. CrossRef Medline

Kang HJ, Kawasawa YI, Cheng F, Zhu Y, Xu X, Li M, Sousa AM, Pletikos M, Meyer KA, Sedmak G, Guennel T, Shin Y, Johnson MB, Krsnik Z, Mayer S, Fertuzinhos S, Umlauf S, Lisgo SN, Vortmeyer A, Weinberger DR, et al. (2011) Spatio-temporal transcriptome of the human brain. Nature 478: 483-489. CrossRef Medline

Kauppinen RA, Alhonen LI (1995) Transgenic animals as models in the study of the neurobiological role of polyamines. Prog Neurobiol 47:545563. CrossRef Medline

Khakh BS, McCarthy KD (2015) Astrocyte calcium signals: from observations to functions and the challenges therein. Cold Spring Harb Perspect Biol 7:a020404. CrossRef Medline

Kucheryavykh YV, Kucheryavykh LY, Nichols CG, Maldonado HM, Baksi K, Reichenbach A, Skatchkov SN, Eaton MJ (2007) Downregulation of Kir4.1 inward rectifying potassium channel subunits by RNAi impairs potassium transfer and glutamate uptake by cultured cortical astrocytes. Glia 55:274-281. CrossRef Medline

Kucheryavykh YV, Shuba YM, Antonov SM, Inyushin MY, Cubano L, Pearson WL, Kurata H, Reichenbach A, Veh RW, Nichols CG, Eaton MJ, Skatchkov SN (2008) Complex rectification of Muller cell Kir currents. Glia 56:775-790. CrossRef Medline

Kuchibhotla KV, Lattarulo CR, Hyman BT, Bacskai BJ (2009) Synchronous hyperactivity and intercellular calcium waves in astrocytes in Alzheimer mice. Science 323:1211-1215. CrossRef Medline

Kuffler SW (1967) Neuroglial cells: physiological properties and a potassium mediated effect of neuronal activity on the glial membrane potential. Proc R Soc Lond B Biol Sci 168:1-21. CrossRef Medline

Kuffler SW, Nicholls JG, Orkand RK (1966) Physiological properties of glial cells in the central nervous system of amphibia. J Neurophysiol 29:768 787. Medline

Lalo U, Verkhratsky A, Pankratov Y (2011) Ionotropic ATP receptors in neuronalglial communication. Semin Cell Dev Biol 22:220-228. CrossRef Medline

Laube G, Veh RW (1997) Astrocytes, not neurons, show most prominent staining for spermidine/spermine-like immunoreactivity in adult rat brain. Glia 19:171-179. CrossRef Medline

Lee S, Yoon BE, Berglund K, Oh SJ, Park H, Shin HS, Augustine GJ, Lee CJ (2010) Channel-mediated tonic GABA release from glia. Science 330: 790-796. CrossRef Medline

Liévens JC, Woodman B, Mahal A, Spasic-Boscovic O, Samuel D, Kerkerian-Le Goff L, Bates GP (2001) Impaired glutamate uptake in the R6 Huntington's disease transgenic mice. Neurobiol Dis 8:807-821. CrossRef Medline

Lioy DT, Garg SK, Monaghan CE, Raber J, Foust KD, Kaspar BK, Hirrlinger PG, Kirchhoff F, Bissonnette JM, Ballas N, Mandel G (2011) A role for glia in the progression of Rett's syndrome. Nature 475:497-500. CrossRef Medline

Ma B, Xu G, Wang W, Enyeart JJ, Zhou M (2014) Dual patch voltage clamp study of low membrane resistance astrocytes in situ. Mol Brain 7:18. CrossRef Medline

Ma L, Xie YP, Zhou M, Chen H (2012) Silent TWIK-1 potassium channels conduct monovalent cation currents. Biophys J 102:L34-36. CrossRef Medline

Magaña JJ, Velázquez-Pérez L, Cisneros B (2013) Spinocerebellar ataxia 
type 2: clinical presentation, molecular mechanisms, and therapeutic perspectives. Mol Neurobiol 47:90-104. CrossRef Medline

Mangiarini L, Sathasivam K, Seller M, Cozens B, Harper A, Hetherington C, Lawton M, Trottier Y, Lehrach H, Davies SW, Bates GP (1996) Exon 1 of the HD gene with an expanded CAG repeat is sufficient to cause a progressive neurological phenotype in transgenic mice. Cell 87:493-506. CrossRef Medline

Maragakis NJ, Rothstein JD (2006) Mechanisms of Disease: astrocytes in neurodegenerative disease. Nat Clin Pract Neurol 2:679-689. Medline

Milenkovic A, Brandl C, Milenkovic VM, Jendryke T, Sirianant L, Wanitchakool P, Zimmermann S, Reiff CM, Horling F, Schrewe H, Schreiber R, Kunzelmann K, Wetzel CH, Weber BH (2015) Bestrophin 1 is indispensable for volume regulation in human retinal pigment epithelium cells. Proc Natl Acad Sci U S A 112:E2630-E2639. CrossRef Medline

Millar ID, Taylor HC, Cooper GJ, Kibble JD, Barhanin J, Robson L (2006) Adaptive downregulation of a quinidine-sensitive cation conductance in renal principal cells of TWIK-1 knockout mice. Pflugers Arch 453:107116. CrossRef Medline

Miller BR, Dorner JL, Shou M, Sari Y, Barton SJ, Sengelaub DR, Kennedy RT, Rebec GV (2008) Up-regulation of GLT1 expression increases glutamate uptake and attenuates the Huntington's disease phenotype in the R6/2 mouse. Neuroscience 153:329-337. CrossRef Medline

Nedergaard M, Rodríguez JJ, Verkhratsky A (2010) Glial calcium and diseases of the nervous system. Cell Calcium 47:140-149. CrossRef Medline

Neul JL, Kaufmann WE, Glaze DG, Christodoulou J, Clarke AJ, Bahi-Buisson N, Leonard H, Bailey ME, Schanen NC, Zappella M, Renieri A, Huppke P, Percy AK; RettSearch Consortium (2010) Rett syndrome: revised diagnostic criteria and nomenclature. Ann Neurol 68:944-950. CrossRef Medline

Nwaobi SE, Lin E, Peramsetty SR, Olsen ML (2014) DNA methylation functions as a critical regulator of Kir4.1 expression during CNS development. Glia 62:411-427. CrossRef Medline

Oh SJ, Han KS, Park H, Woo DH, Kim HY, Traynelis SF, Lee CJ (2012) Protease activated receptor 1-induced glutamate release in cultured astrocytes is mediated by Bestrophin- 1 channel but not by vesicular exocytosis. Mol Brain 5:38. CrossRef Medline

Oliver D, Hahn H, Antz C, Ruppersberg JP, Fakler B (1998) Interaction of permeant and blocking ions in cloned inward-rectifier $\mathrm{K}+$ channels. Biophys J 74:2318-2326. CrossRef Medline

Olsen ML, Higashimori H, Campbell SL, Hablitz JJ, Sontheimer H (2006) Functional expression of Kir4.1 channels in spinal cord astrocytes. Glia 53:516-528. CrossRef Medline

Oredsson SM (2003) Polyamine dependence of normal cell-cycle progression. Biochem Soc Trans 31:366-370. CrossRef Medline

Orkand RK, Nicholls JG, Kuffler SW (1966) Effect of nerve impulses on the membrane potential of glial cells in the central nervous system of amphibia. J Neurophysiol 29:788-806. Medline

Panatier A, Vallée J, Haber M, Murai KK, Lacaille JC, Robitaille R (2011) Astrocytes are endogenous regulators of basal transmission at central synapses. Cell 146:785-798. CrossRef Medline

Pannasch U, Rouach N (2013) Emerging role for astroglial networks in information processing: from synapse to behavior. Trends Neurosci 36: 405-417. CrossRef Medline

Pannasch U, Vargová L, Reingruber J, Ezan P, Holcman D, Giaume C, Syková E, Rouach N (2011) Astroglial networks scale synaptic activity and plasticity. Proc Natl Acad Sci U S A 108:8467-8472. CrossRef Medline

Pannasch U, Freche D, Dallérac G, Ghézali G, Escartin C, Ezan P, CohenSalmon M, Benchenane K, Abudara V, Dufour A, Lübke JH, Déglon N, Knott G, Holcman D, Rouach N (2014) Connexin 30 sets synaptic strength by controlling astroglial synapse invasion. Nat Neurosci 17:549558. CrossRef Medline

Park H, Oh SJ, Han KS, Woo DH, Park H, Mannaioni G, Traynelis SF, Lee CJ (2009) Bestrophin-1 encodes for the Ca2+-activated anion channel in hippocampal astrocytes. J Neurosci 29:13063-13073. CrossRef Medline

Park H, Han KS, Oh SJ, Jo S, Woo J, Yoon BE, Lee CJ (2013) High glutamate permeability and distal localization of Best 1 channel in CA1 hippocampal astrocyte. Mol Brain 6:54. CrossRef Medline

Park H, Han KS, Seo J, Lee J, Dravid SM, Woo J, Chun H, Cho S, Bae JY, An $\mathrm{H}$, Koh W, Yoon BE, Berlinguer-Palmini R, Mannaioni G, Traynelis SF, Bae YC, Choi SY, Lee CJ (2015) Channel-mediated astrocytic glutamate modulates hippocampal synaptic plasticity by activating postsynaptic NMDA receptors. Mol Brain 8:7. CrossRef Medline
Pegg AE (2014) The function of spermine. IUBMB Life 66:8-18. CrossRef Medline

Poopalasundaram S, Knott C, Shamotienko OG, Foran PG, Dolly JO, Ghiani CA, Gallo V, Wilkin GP (2000) Glial heterogeneity in expression of the inwardly rectifying $\mathrm{K}(+)$ channel, Kir4.1, in adult rat CNS. Glia 30:362372. CrossRef Medline

Ransom BR, Goldring S (1973) Ionic determinants of membrane potential of cells presumed to be glia in cerebral cortex of cat. J Neurophysiol 36:855-868. Medline

Rouach N, Koulakoff A, Abudara V, Willecke K, Giaume C (2008) Astroglial metabolic networks sustain hippocampal synaptic transmission. Science 322:1551-1555. CrossRef Medline

Sala-Rabanal M, Kucheryavykh LY, Skatchkov SN, Eaton MJ, Nichols CG (2010) Molecular mechanisms of EAST/SeSAME syndrome mutations in Kir4.1 (KCNJ10). J Biol Chem 285:36040-36048. CrossRef Medline

Scemes E, Spray DC (2012) Extracellular K(+) and astrocyte signaling via connexin and pannexin channels. Neurochem Res 37:2310-2316. CrossRef Medline

Scholl UI, Choi M, Liu T, Ramaekers VT, Häusler MG, Grimmer J, Tobe SW, Farhi A, Nelson-Williams C, Lifton RP (2009) Seizures, sensorineural deafness, ataxia, mental retardation, and electrolyte imbalance (SeSAME syndrome) caused by mutations in KCNJ10. Proc Natl Acad Sci U S A 106:5842-5847. CrossRef Medline

Seifert G, Hüttmann K, Binder DK, Hartmann C, Wyczynski A, Neusch C, Steinhäuser C (2009) Analysis of astroglial K+ channel expression in the developing hippocampus reveals a predominant role of the Kir4.1 subunit. J Neurosci 29:7474-7488. CrossRef Medline

Shin JY, Fang ZH, Yu ZX, Wang CE, Li SH, Li XJ (2005) Expression of mutant huntingtin in glial cells contributes to neuronal excitotoxicity. J Cell Biol 171:1001-1012. CrossRef Medline

Sibille J, Pannasch U, Rouach N (2014) Astroglial potassium clearance contributes to short-term plasticity of synaptically evoked currents at the tripartite synapse. J Physiol 592:87-102. CrossRef Medline

Sibille J, Dao Duc K, Holcman D, Rouach N (2015) The neuroglial potassium cycle during neurotransmission: role of Kir4.1 channels. PLoS Comput Biol 11:e1004137. CrossRef Medline

Sicca F, Imbrici P, D’Adamo MC, Moro F, Bonatti F, Brovedani P, Grottesi A, Guerrini R, Masi G, Santorelli FM, Pessia M (2011) Autism with seizures and intellectual disability: possible causative role of gain-of-function of the inwardly-rectifying K+ channel Kir4.1. Neurobiol Dis 43:239-247. CrossRef Medline

Skatchkov SN, Eaton MJ, Krusek J, Veh RW, Biedermann B, Bringmann A, Pannicke T, Orkand RK, Reichenbach A (2000) Spatial distribution of spermine/spermidine content and $\mathrm{K}(+)$-current rectification in frog retinal glial (Muller) cells. Glia 31:84-90. CrossRef Medline

Skatchkov SN, Woodbury-Fariña MA, Eaton M (2014) The role of glia in stress: polyamines and brain disorders. Psychiatr Clin North Am 37:653678. CrossRef Medline

Stehberg J, Moraga-Amaro R, Salazar C, Becerra A, Echeverría C, Orellana JA, Bultynck G, Ponsaerts R, Leybaert L, Simon F, Sáez JC, Retamal MA (2012) Release of gliotransmitters through astroglial connexin 43 hemichannels is necessary for fear memory consolidation in the basolateral amygdala. FASEB J 26:3649-3657. CrossRef Medline

Sun W, McConnell E, Pare JF, Xu Q, Chen M, Peng W, Lovatt D, Han X, Smith Y, Nedergaard M (2013) Glutamate-dependent neuroglial calcium signaling differs between young and adult brain. Science 339:197200. CrossRef Medline

Tada Y, Horio Y, Kurachi Y (1998) Inwardly rectifying K+ channel in retinal Muller cells: comparison with the KAB-2/Kir4.1 channel expressed in HEK293T cells. Jpn J Physiol 48:71-80. CrossRef Medline

Tang X, Hang D, Sand A, Kofuji P (2010) Variable loss of Kir4.1 channel function in SeSAME syndrome mutations. Biochem Biophys Res Commun 399:537-541. CrossRef Medline

Theis M, Söhl G, Eiberger J, Willecke K (2005) Emerging complexities in identity and function of glial connexins. Trends Neurosci 28:188-195. CrossRef Medline

Tong X, Ao Y, Faas GC, Nwaobi SE, Xu J, Haustein MD, Anderson MA, Mody I, Olsen ML, Sofroniew MV, Khakh BS (2014) Astrocyte Kir4.1 ion channel deficits contribute to neuronal dysfunction in Huntington's disease model mice. Nat Neurosci 17:694-703. CrossRef Medline

Torres A, Wang F, Xu Q, Fujita T, Dobrowolski R, Willecke K, Takano T, 
Nedergaard M (2012) Extracellular Ca(2)(+) acts as a mediator of communication from neurons to glia. Sci Signal 5:ra8. Medline

Verkhratsky A, Reyes RC, Parpura V (2014) TRP channels coordinate ion signalling in astroglia. Rev Physiol Biochem Pharmacol 166:1-22. Medline

Vit JP, Ohara PT, Bhargava A, Kelley K, Jasmin L (2008) Silencing the Kir4.1 potassium channel subunit in satellite glial cells of the rat trigeminal ganglion results in pain-like behavior in the absence of nerve injury. J Neurosci 28:4161-4171. CrossRef Medline

Wallraff A, Köhling R, Heinemann U, Theis M, Willecke K, Steinhäuser C (2006) The impact of astrocytic gap junctional coupling on potassium buffering in the hippocampus. J Neurosci 26:5438-5447. CrossRef Medline

Wang W, Putra A, Schools GP, Ma B, Chen H, Kaczmarek LK, Barhanin J, Lesage F, Zhou M (2013) The contribution of TWIK-1 channels to astrocyte $\mathrm{K}(+)$ current is limited by retention in intracellular compartments. Front Cell Neurosci 7:246. Medline

Wilcock DM, Vitek MP, Colton CA (2009) Vascular amyloid alters astrocytic water and potassium channels in mouse models and humans with Alzheimer's disease. Neuroscience 159:1055-1069. CrossRef Medline

Woo DH, Han KS, Shim JW, Yoon BE, Kim E, Bae JY, Oh SJ, Hwang EM, Marmorstein AD, Bae YC, Park JY, Lee CJ (2012) TREK-1 and Best1 channels mediate fast and slow glutamate release in astrocytes upon GPCR activation. Cell 151:25-40. CrossRef Medline

Wu Z, Guo Z, Gearing M, Chen G (2014) Tonic inhibition in dentate gyrus impairs long-term potentiation and memory in an Alzheimer's [corrected] disease model. Nat Commun 5:4159. Medline

Yasui DH, Peddada S, Bieda MC, Vallero RO, Hogart A, Nagarajan RP, Thatcher KN, Farnham PJ, Lasalle JM (2007) Integrated epigenomic analyses of neuronal $\mathrm{MeCP} 2$ reveal a role for long-range interaction with active genes. Proc Natl Acad Sci U S A 104:19416-19421. CrossRef Medline

Yoon BE, Jo S, Woo J, Lee JH, Kim T, Kim D, Lee CJ (2011) The amount of astrocytic GABA positively correlates with the degree of tonic inhibition in hippocampal CA1 and cerebellum. Mol Brain 4:42. CrossRef Medline

Yoon BE, Woo J, Chun YE, Chun H, Jo S, Bae JY, An H, Min JO, Oh SJ, Han KS, Kim HY, Kim T, Kim YS, Bae YC, Lee CJ (2014) Glial GABA, synthesized by monoamine oxidase B, mediates tonic inhibition. J Physiol 592:4951-4968. CrossRef Medline

Zhou M, Xu G, Xie M, Zhang X, Schools GP, Ma L, Kimelberg HK, Chen H (2009) TWIK-1 and TREK-1 are potassium channels contributing significantly to astrocyte passive conductance in rat hippocampal slices. J Neurosci 29:8551-8564. CrossRef Medline 